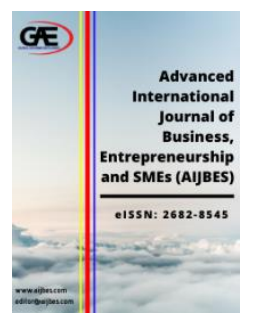

\author{
ADVANCED INTERNATIONAL JOURNAL OF \\ BANKING, ACCOUNTING AND FINANCE \\ (AIJBAF) \\ www.aijbaf.com
}

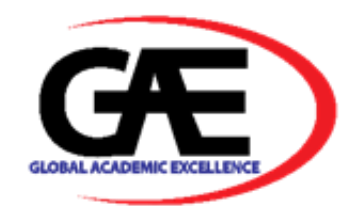

\title{
A STUDY ON FACTORS THAT AFFECTING THE INDIVIDUALS' INVESTMENT DECISION MAKING IN MALAYSIA INVESTMENT BANKS
}

\author{
Haniza Hashim $^{1}$, Nur Baiti Shafee ${ }^{2}$, Shadia Suhaimi ${ }^{3}$, Siti Nurul Huda Mohd ${ }^{4}$, Ku Lye Ting ${ }^{5}$ \\ 1 Faculty of Business, Multimedia University (MMU), Malaysia \\ Email: haniza.hashim@mmu.edu.my \\ 2 Faculty of Business, Multimedia University (MMU), Malaysia \\ Email: norbaiti.shafee@mmu.edu.my \\ 3 Faculty of Business, Multimedia University (MMU), Malaysia \\ Email: shadia.suhaimi@mmu.edu.my \\ $4 \quad$ Faculty of Business, Multimedia University (MMU), Malaysia \\ Email: huda.mohd@mmu.edu.my \\ 5 Faculty of Business, Multimedia University (MMU), Malaysia \\ Email: 1132702682@mmu.edu.my
}

\section{Article Info:}

\section{Article history:}

Received date: 18.12 .2019

Revised date: 14.01.2020

Accepted date: 04.02.2021

Published date: 01.03.2021

\section{To cite this document:}

Hashim, H., Shafee, N. B., Suhaimi, S., Mohd, S. N. H., \& Ku, L. T. (2021). A Study on Factors That Affecting The Individuals' Investment Decision Making in Malaysia Investment Banks. Advanced International Journal of Banking, Accounting, and Finance, 3 (6), 01-12.

DOI: 10.35631/AIJBAF.36001.

\begin{abstract}
:
The research paper is aim to study about the factors that influence individuals for making their investment decision. Behavioural finance examines one of the central factors that influence investors' decision-making. In behavioural finance, the characteristics of individual and past information structure can significantly affect decision making. Thus, this study is to examine the factors of risk and expected return, demographic factors, macroeconomic factors, and advocate recommendation. Individuals with different perceptions on investment will be likely to have their own viewpoint. Therefore, various opinion s will be getting from different types of investors in making an investment decision. This research is conducted to examine the factors that affect individuals' investment decision-making. There is 150 number of working adults who will be selected as the target respondents in filling in the questionnaire forms that distributed by the researcher. This research is for the purpose to fill in the gap of the previous researches which have been studied before. This research has identified that risk and expected return, demographic factors, macroeconomic factors, and advocate recommendation have a significant relationship in investment decision making. This research illustrates to help other researchers for the investment decision-making process.
\end{abstract}




\section{Background of Study}

Investment is one type of business activity that investors expect it will help their business to flourish in the long run. Investment banking is a financial intermediary that focuses primarily in selling securities and underwriting the issuance of new equity shares in order to raise capital funds (Investment Bank, n.d.). It is a form of banking that differs with conventional banking because capital requirement is required for individual investor and business entity. Investment bank helps companies, government and other business entities to raise money or funds by selling securities in the primary market. Investment bank also provides the services to corporate sectors and investors such as advisory services and acts as intermediaries in trading for clients who are investors and issuers. Example of Investment Bank are Affin Investment Bank, Alliance Investment Bank, CIMB Bank, Am Investment Bank, Hong Leong Investment Bank and so on (Bank Negara Malaysia, 2005).

\section{Problem Statement}

Financial industry in Malaysia growth throughout the years, it provides the range of products and services that enables investors and businesses to do the investment. The decision making process tends to be more hesitated because of the several alternatives of options that provided. The behavioural factors are taken into the consideration of behavioural finance (Ali \& Tariq, 2013). Besides that, the weaker of Malaysian Ringgit also will be one of the factor that been taken into consideration. Furthermore, investment decision need to be clearly defined thorough the analysis based on the numeral number of factors. Therefore, this study will analyse the factors that affecting the individuals' investment decision making in Investment banks.

\section{Research Questions}

1. Do risk and expected return of the investment have a significant relationship on individuals' investment decision making in Malaysia Investment banks?

2. Do demographic factors have a significant relationship on individuals' investment decision making in Malaysia Investment banks?

3. Do macroeconomic factors have a significant relationship on individuals' investment decision making in Malaysia Investment banks?

4. Do advocate recommendations have a significant relationship on individuals' investment decision making in Malaysia Investment banks?

\section{Significance for Study}

This study can help Investment bank get to know the customer preferences and enlarge their customer base. Furthermore, this study can help Insurance Companies to enlarge their product. This is because Insurance Companies also providing investment banking services to some of the corporation entity such as Alliance Insurance Company.

\section{Limitation of the Study}

Respondents for this research are only from Melaka instead of Malaysia as a whole. This is because of the limitation of time and cost. Besides that, target group for this study are working 
Volume 3 Issue 6 (March 2021) PP. 01-12

DOI 10.35631/AIJBAF.36001

adults whose start joining the working environment and this type of people have limited amount of income to invest.

\section{Literature Review}

\section{Risk and Expected Return on Investment}

There are many factors that may affect investors when making an investment decision, but then risk and expected return are one of the important variable that play an essential role in decision making (Walia \& Kiran, 2009). In generally, McGraw-Hill (n.d.), describes these two variables which are risk and expected return have the significant relationship between each others. Investors normally are more prudential when making investment decision and they are rationality demand on higher return on particular stock at minimum of risk. But then, it is impossible for market to provide abnormal return. Monisola (2012), defined risk might gain uncertainty and created losses for investors in the particular project. Besides, RIMS Executive Report (2012) claims that every investor has to bear with the higher risk of the project in the return of higher rewards as the compensation of the high level of risk had been taken. This kind of investors is called risk aversion. Tversky \& Kahneman (2007), defined risk aversion is an individual who desire high return with minimum of risk in order to avoid uncertainty of outcome. According to Sajid (2015), it defined that risk aversion has negative impact when trading in investment activities. Thus, being risk aversion will directly affects investors in making the bad decision which stated by Walia \& Kiran (2009). The researches of Qureshi, Rehman, \& Hunjra (2012) that studies behavioural of investors in risk taking had recognize that risk aversion might be the crucial factors that affecting decision making under the environment of uncertainty. By contrary, investor who is classified as risk seeking is more likely attracted to risk, which means that they are looking for greater risk of investment project but not concern about the expected return no matter it is little return or high amount of return. Therefore, Gärling et al. (2010) defined that different types of investor behaviour tend to have different risk and expected return towards particular investment project. Additionally, expected return is the return that investor expected while making an investment. It needs to clearly define as well whether investors are making long term or short term investment decision. Amromin $\&$ Sharpe (2009) explained that this is because expected return tends to have strongly influence on the short-term investment decision.

Hypothesis 1: There is a relationship between risk and expected return factor towards investment decision making.

\section{Demographic Factor}

Das \& Jain (2014) stated that demographic variables play an important role for people making their investment decision. Some studies are conducted to examine the relationship between demographic factors and investment decision making (Sadiq \& Ishaq, 2014). People with different gender, level of income, ages and occupation tends to have different attitude towards investment decision making (Collard, 2009).

\section{Gender}

Arti \& Sunita (2011), defined gender might be the most effective factors that influencing the individuals making their investment decision. This is because the variable of emotional attitudes differs among men and women that stated by Sadiq \& Ishaq (2014). According to Albaity \& Rahman (2012), it defined male investors are more likely to bear more risk compare Copyright (C) GLOBAL ACADEMIC EXCELLENCE (M) SDN BHD - All rights reserved 
Volume 3 Issue 6 (March 2021) PP. 01-12

DOI 10.35631/AIJBAF.36001

to female investors. Female investors are more conservative because they spending more of their capital in long term investments and relying more on brokers when investing in particular portfolio (Lutfi, 2010). In general, female mostly are classified into risk aversion while male as risk taker.

\section{Level of Income}

Islamoglu, Apan, \& Ayvali (2015), defined level of income of every investor also will affect individual in making investment decision. For example, Lutfi (2010) defined that people with a higher level of income might invest their funds in more risky investment portfolio (Lutfi, 2010) due to large amount of income gives permission for them to take risks. Besides that, Jain \& Mandot (2012) had studied about financial wealth have a significant impact on the level of risk that had been chosen in each of the portfolio. Tseng \& Search (2012) stated that investors with the high level of income can increase their richest information searching. Therefore, income level also is one of the factors to influence individuals' investment decision making.

Ages

Chandra (2008) defined that investment decision making of individuals' investors also based on their ages. Young investors looking for risky project whereas older investors prefer on stability (Sadiq \& Ishaq, 2014). This is because old investors have more experience compare to young investors. Thus, they tend to know more information about investment and can make the better investment choices (Sadiq \& Ishaq, 2014).

\section{Occupation}

Rajdev (2013) had defined that the idea of investment decision also will be affected by career concern. People who has own business will have more opportunities to invest compare to those who work with others. This is because they have more extra income and access to capital market. According to Sadiq \& Ishaq (2014) explained that those people who generate the profit with their own business are more likely to gain the extra return with the higher level of risk taking.

Hypothesis 2: There is a relationship between demographic factor towards investment decision making.

\section{Macroeconomic Factors}

Johnston \& StudioD (2016) defined that individuals' making investment decision also depends on the performance of economy such as microeconomic as well as macroeconomic perspective. But then, Bialowolski \& Weziak-bialowolska (2013) argued that macroeconomic factors serves as most crucial determinant for people to change their mind invest in particular project. Ramasamy \& Abar (2015) defined that macroeconomic factor such as interest rate, inflation rate and exchange rate might influenced investors invest their funds in the capital market. Haritha \& Uchil (2016) Firstly, Singh (2010) stated that changes in risk premium, measures for unanticipated inflation rate or volatile inflation lead to explain the uncertainty of stock market price. Macroeconomic factors can be classified under systematic risks which cannot be eliminated. Investors should adapt the environment change in order to generate profit from their investment. Lee \& Management (2007) had claims that the price movement in capital market which included the changes of interest rate, exchange rate and even for inflation rate would lead to a significant level of impact on stock prices. Moreover, Schwert, Maysami and Koh and Koutoulas and Kryzanoski had given evidence which is in the case of Singapore and Copyright (C) GLOBAL ACADEMIC EXCELLENCE (M) SDN BHD - All rights reserved 
Volume 3 Issue 6 (March 2021) PP. 01-12

DOI 10.35631/AIJBAF.36001

Canada, it prove that the macroeconomic factors have a significant effects on the stock market price in journal (Rahman, Sidek, \& Tafri, 2009). Individual investors invest to gain profit from the investment, and this is the reason why they find that macroeconomic factors are important to them.

Hypothesis 3: There is a relationship between macroeconomic factor towards investment decision making.

\section{Advocate Recommendation}

Advocate factors such as family member opinion, recommendation by brokerage house, suggestion by friends and co-workers or firm recommendation had significant impact to investment decision making. Chong \& Lai (2011) defined this factor occur when investors who are non-financial experts and have little investment experience and knowledge in deciding the project going to invest so this factor can help them in investment decision making. Furthermore, researches of Jagongo \& Mutswenje (2014), defined that the investors' decision mostly affected by advocate recommendation when they used analysts recommendation in short term decision whether to buy or sell the stock because short term investment more risky compared to long term investment.

Hypothesis 4: There is a relationship between advocate recommendation factor towards investment decision making.

\section{Individuals' Investment Decision Making}

Jahanzeb, Muneer, \& Rehman (2012) stated that investment decision making is such a very difficult job for every investor. Investors invest to gain extra profit but if they make wrong decision, they will not get loss. Furthermore, Beersi et al. (2002) defined that decision making is easily to be affected because of the complexity. . Some of the investors do not have necessary knowledge to predict all possible alternatives and they have limited knowledge as well to rank all the alternatives by calculating each of the cost incur and benefit provide. Besides that, each people normally have different perspective and perception (Role, The, Adler, \& Rose, 2010) while making investment decision making. There are many factors may influence the individuals; decision making but in this research study, it only focusses on four different variables namely as risk and expected return, demographic factors, macroeconomic factors and advocate recommendations.

\section{Research Methodology}

This research is study about the factors that affecting individuals' investment decision making in Malaysia Investment Bank. In this research study, questionnaire design method was being used for collecting the data. Questionnaire can be divided to two (2) main sections. The first section was designing to collect the demographic information from the respondents which were including gender, ages, occupation, income level and marital status. Nominal scale had been used to measure in this section. The second section was used to measure four (4) independent variables which were risk and expected return, demographic factors, macroeconomic factors and advocate recommendations by using interval scale. Respondents were asked to indicate on the five point, which were ranging from " $1=$ strongly disagree" to " $5=$ strongly agree". Questionnaire had been distributed to 150 samples working adult that live in Malacca, Malaysia. Samples are randomly selected from three (3) main area of shopping malls in Malacca. People with the different age, gender, race and occupation were selected in order to Copyright (C) GLOBAL ACADEMIC EXCELLENCE (M) SDN BHD - All rights reserved 
Volume 3 Issue 6 (March 2021) PP. 01-12

DOI 10.35631/AIJBAF.36001

analyse the individuals' investors according to their different investment decision making. Data collection for this research focused on primary data. Primary data is collected by researcher and is originally from the respondents. Data that had been collected were analysed using used Statistical Package for Social Science (SPSS).

\section{Data Analysis and Findings}

\section{Demographic Profile}

Table 1: Frequency and percent analysis of respondents

\begin{tabular}{|l|l|c|c|}
\hline \multicolumn{2}{|c|}{ Variables } & Frequencies & Percent (\%) \\
\hline \multirow{4}{*}{ Gender } & Male & 71 & 47.3 \\
\cline { 2 - 4 } & Female & $\mathbf{7 9}$ & $\mathbf{5 2 . 7}$ \\
\hline \multirow{5}{*}{ Occupation } & Below 20 & 28 & 18.7 \\
\cline { 2 - 4 } & $\mathbf{2 1 - 3 0}$ & $\mathbf{8 0}$ & $\mathbf{5 3 . 3}$ \\
\cline { 2 - 4 } & $31-40$ & 31 & 20.7 \\
\cline { 2 - 4 } & Above 40 & 11 & 7.3 \\
\hline \multirow{5}{*}{ Income Level } & Student & $\mathbf{7 5}$ & $\mathbf{5 0 . 0}$ \\
\cline { 2 - 4 } & Businessman & 55 & 36.7 \\
\cline { 2 - 4 } & Housewife & 16 & 10.7 \\
\cline { 2 - 4 } & Retired & 4 & 2.7 \\
\cline { 2 - 4 } & Below RM2000 & $\mathbf{8 3}$ & $\mathbf{5 5 . 3}$ \\
\cline { 2 - 4 } & RM2000-RM3000 & 19 & 12.7 \\
\cline { 2 - 4 } & RM3000-RM4000 & 24 & 16.0 \\
\cline { 2 - 4 } & Above RM4000 & 24 & 16.0 \\
\hline \multirow{5}{*}{ Marital Status } & Single & $\mathbf{1 0 2}$ & 32.0 \\
\cline { 2 - 4 } & Married & 48 & \\
\hline
\end{tabular}

$*$ Sample size $=150$

By referring to table 6 , the first variables of gender which were 71 of male (47.3\%) and 49 of female (52.7) had conducted in this research and female respondents were slightly more than male respondents. Besides that, for the age of respondents, most of them are in the age of 21 to 30 years old which stands for 80 out of 150 respondents $(53.3 \%)$ and followed by the respondents which in the age of 31-40 years old that allocated in second highest place and it was represented 31 out of $150(20.7 \%)$. The respondents who are below 20 years old and 40 years old above were occupied 28 out of $150(18.7 \%)$ and 11 out of $150(7.3 \%)$ respectively. Furthermore, in the category of occupation, majority of them were students which represented 75 out of $150(50 \%)$. Followed by the total number of 55 out of $150(36.7 \%)$ were in the career of businessman. Household and retired were occupied 16 and 4 out of 150 in each of categories which ate $10.7 \%$ and $2.7 \%$ respectively. Apart from that, income levels had been categories into 4 classes, and it found that most of the respondents' income levels were below RM2000 which represented $55.3 \%$ or 83 out of 150 respondents. Followed by another two categories of income level which are RM3000 to RM4000 and above RM4000 were occupied the same number of respondents which is $16 \%$ or 24 out of 150 respondents and the lowest percentage were be in the categories of RM2000 to RM3000 which is 19 out of 150 respondents (12.7). marital status had been classified into two major categories which are single and married. A majority of respondents were in the status of single which represented 102 out of 150 Copyright $\odot$ GLOBAL ACADEMIC EXCELLENCE (M) SDN BHD - All rights reserved 
Volume 3 Issue 6 (March 2021) PP. 01-12

DOI 10.35631/AIJBAF.36001

respondents $(68 \%)$. Followed by 48 numbers of respondents were in the married status which represented 48 out of $150(32 \%)$.

\section{Descriptive Analysis}

Table 2: Descriptive analysis for dependent and independent variable.

\begin{tabular}{|c|c|c|}
\hline Question & Mean & Std. Deviation \\
\hline Investment decision making & 4.23 & 0.59 \\
\hline Risk and expected return & 4.12 & 0.69 \\
\hline Demographic factors & 3.99 & 0.75 \\
\hline Macroeconomic factors & 4.12 & 0.62 \\
\hline Advocate recommendation & 3.94 & 0.82 \\
\hline
\end{tabular}

In descriptive analysis, it shows the mean and standard deviation between dependent and independent variables. A dependent variable of this research which is investment decision making and the independent variables which included risk and expected return, demographic factors, macroeconomic factors and advocate recommendation. Mean of investment decision making was 4.23 which is higher than the neutral point of 3.00. Therefore, it can be explained that majority of respondents would consider the factors associated with investment decision making. Besides that, the mean of risk and expected return was 4.12 which were higher than neutral point of 3.00 and this result explained that majority of respondents were considered the factor of risk and expected return in making investment decision. In addition, the demographics factors which are the mean of 3.99 were higher than the neutral point of 3.00 and shows that most of the respondents were considered the demographic factors for investment decision. Furthermore, the mean of macroeconomic factors was 4.12 which higher than the neutral point of 3.00 and this confirmed that majority of respondents were aware for the macroeconomic factors when making investment decision. Lastly, the mean of advocate recommendation was 3.94 which higher than the neutral point of 3.00 and it can be explained that most of respondents were considered this factor when making investment decision.

\section{Reliability of Measures}

Table 3: Reliability test on all variables for Cronbach's Alpha

\begin{tabular}{|c|c|c|}
\hline Variables & Number of items & Cronbach's Alpha \\
\hline Investment decision making & 4 & 0.703 \\
\hline Risk and expected return & 4 & 0.704 \\
\hline Demographic factors & 4 & 0.704 \\
\hline Macroeconomic factors & 4 & 0.724 \\
\hline Advocate recommendation & 4 & 0.882 \\
\hline
\end{tabular}

Referring to this table, there were total 5 variables have been tested which are included investment decision making, risk and expected return, demographic factors, macroeconomic factors and advocate recommendation. Through the result of Cronbach's Alpha from the SPSS software, it shows that these variables varied from 0.703 to 0.882 . All the variables obtained 
Volume 3 Issue 6 (March 2021) PP. 01-12

DOI 10.35631/AIJBAF.36001

more than 0.7. Therefore, it can be explained that all the variables were considered as good in term of reliability test.

Multiple Regression Analysis

Table 4: Regression analysis model summary

\begin{tabular}{|c|c|c|c|c|}
\hline \multicolumn{3}{|c|}{ Model Summary } \\
\hline Model & $\mathrm{R}$ & R Square & $\begin{array}{c}\text { Adjusted R } \\
\text { Square }\end{array}$ & Std. Error of the Estimate \\
\hline 1 & $.723^{\mathrm{a}}$ & .523 & .510 & .41602 \\
\hline
\end{tabular}

a. Predictors: (Constant), Risk and Expected Return, Demographic factors, Macroeconomic factors and Advocate Recommendation

b. Dependent variable: Investment Decision Making

Multiple regression analysis is a technique that used to determine the effect of one or more predictors and dependent variable (outcome variable). Regression allows researchers to make the statement of one or more independent variables to predict the value of dependent variable. In this research, the multiple regressions were used to examine the relationship between the dependent variable and independent variables. By referring to this table, the value of $\mathrm{R}$ Square as 0.523 which indicates that $52.3 \%$ of the variance in the dependent variable is explained by the independent variables in the model.

\section{ANOVA}

Table 5: ANOVA

\begin{tabular}{|c|c|c|c|c|c|c|}
\hline \multicolumn{7}{|c|}{ ANOVA $^{\text {a }}$} \\
\hline \multirow{2}{*}{\begin{tabular}{c} 
Model \\
\multirow{2}{*}{1}
\end{tabular}} & $\begin{array}{c}\text { Sum of } \\
\text { Squares }\end{array}$ & df & $\begin{array}{c}\text { Mean } \\
\text { Square }\end{array}$ & F & Sig. \\
\cline { 2 - 8 } & Regression & 27.488 & 4 & 6.872 & 39.707 & $.000^{\text {b }}$ \\
\cline { 2 - 8 } & Residual & 25.095 & 145 & .173 & & \\
\cline { 2 - 8 } & Total & 52.583 & 149 & & & \\
\hline
\end{tabular}

a. Dependent Variable: Investment Decision Making

c. Predictors: (Constant), Risk and Expected Return, Demographic Factors, Macroeconomic Factors and Advocate Recommendation

ANOVA table describes the overall variance that accounted in the model. ANOVA was used to determine the relationship between dependent and independent variables. Table 5 shows that the F-value of 39.707 with p-value of 0.000 which indicates that there is significant at 0.005 alpha. 
Table 6: Coefficients

\begin{tabular}{|c|c|c|c|c|c|c|}
\hline \multicolumn{7}{|c|}{ Coefficients $^{\mathrm{a}}$} \\
\hline & \multirow[t]{2}{*}{ Model } & \multicolumn{2}{|c|}{$\begin{array}{l}\text { Unstandardize } \\
\text { d Coefficients }\end{array}$} & \multirow{2}{*}{$\begin{array}{c}\begin{array}{c}\text { Standardize } \\
\mathrm{d} \\
\text { Coefficients }\end{array} \\
\text { Beta }\end{array}$} & \multirow[t]{2}{*}{$\mathrm{t}$} & \multirow[t]{2}{*}{ Sig. } \\
\hline & & B & $\begin{array}{l}\text { Std. } \\
\text { Error }\end{array}$ & & & \\
\hline \multirow[t]{5}{*}{1} & (Constant) & 1.194 & .273 & & 4.370 & .000 \\
\hline & $\begin{array}{c}\text { Risk and Expected } \\
\text { Return }\end{array}$ & .494 & .059 & .575 & 8.317 & .000 \\
\hline & Demographic Factors & -.119 & .056 & -.151 & -2.127 & .035 \\
\hline & Macroeconomic Factors & .190 & .067 & .199 & 2.840 & .005 \\
\hline & $\begin{array}{c}\text { Advocate } \\
\text { Recommendation }\end{array}$ & .178 & .044 & .246 & 4.032 & .000 \\
\hline
\end{tabular}

a. Dependent Variable: Investment Decision Making

This table shows all the p-value by each of the variables. If the p-value is lower than 0.05 (pvalue $<0.05)$, it means the $\mathrm{p}$-value can be counted as significant. Whereas, if the p-value is greater than 0.05 ( $\mathrm{p}$-value $<0.05$ ), it means the $\mathrm{p}$-value cannot is not significant. Table 11 shows that the variables of risk and expected return and advocate recommendation obtained the p-value of 0.000 and it were as highest significant level. Another variable such as demographic factors had obtained the p-value of 0.035 which lower than 0.05 and it counted as significant. Lastly, the macroeconomic factors also counted as significant since the p-value is lower than 0.05 which is 0.005 .

\section{Hypothesis Testing}

Table 7: Hypothesis test

\begin{tabular}{|c|l|c|c|}
\hline No & \multicolumn{1}{|c|}{ Hypothesis } & P-value & Decision \\
\hline H1 & $\begin{array}{l}\text { Risk and expected return has a } \\
\text { relationship with the investment } \\
\text { decision making. }\end{array}$ & 0.000 & supported \\
\hline H2 & $\begin{array}{l}\text { Demographic factors have a } \\
\text { relationship with the investment } \\
\text { decision making. }\end{array}$ & $\begin{array}{l}\text { supported } \\
\text { Macroeconomic factors have a } \\
\text { delationship with the investment } \\
\text { decision making. }\end{array}$ & $\begin{array}{l}\text { supported } \\
\text { relationship with the investment } \\
\text { decision making. }\end{array}$ \\
\hline
\end{tabular}

Referring to this table, the p-value of all the four independent variables were lower than 0.05 .. Therefore, it can conclude that all the four independent variables were considered significant 
Volume 3 Issue 6 (March 2021) PP. 01-12

DOI 10.35631/AIJBAF.36001

since their p-values are lower than0.05. It had the strong evident stated that all the independent variables were supported.

\section{Conclusion}

Finding of this study shows positive relationship between these four factors towards investment decision making in Malaysia Investment Bank. These four factors are risk and expected return, demographic factor, macroeconomic factor and advocate recommendation. All of these variables had been tested and show the significant relationship between the four independent variables and dependent variable. Therefore, it can be concluded that Investment banks should take these four variables in concern. This research considers very important for Investment banks in order to identify the main factors that will affect the individuals' in making the investment decision in the particular bank.

\section{References}

Ali, I., \& Tariq, A. (2013). Factors Affecting Individual Equity Investor's Decision Making in Pakistan, 19. Retrieved from http://www.psp-ltd.com/JIEB_3_1_2013.pdf

Amromin, G., \& Sharpe, S. a. (2009). Expectations of Risk and Return among Household Investors: Are their Sharpe Ratios Countercyclical? Board of Governors of the Federal Reserve System Working Paper, 3. Retrieved from http://ezproxy.lib.monash.edu.au/login?url=http://search.ebscohost.com/login.aspx?di rect $=$ true $\& d \mathrm{~b}=\mathrm{bth} \& \mathrm{AN}=35912536 \&$ site $=$ ehost-live $\&$ scope $=$ site

Albaity, M., \& Rahman, M. (2012). Behavioural Finance and Malaysian Culture. International Business Research, 5(11), 65. http://doi.org/10.5539/ibr.v5n11p65

Arti, G., \& Sunita, S. (2011). Difference in Gender Attitude in Investment Decision Making in India. Research Journal of Finance and Accounting, 2(12), 1. Retrieved from http://www.iiste.org/Journals/index.php/RJFA/article/viewFile/1292/1212

Bank Negara Malaysia. (2005). Guidelines on Investment Banks, 5. Retrieved from http://www.bnm.gov.my/guidelines/01_banking/04_prudential_stds/12_investmentba nk_guideline.pdf

Beersi, P. J., Kirschner, P. a, Technology, E., Bossche, P. Van Den, Development, E., \& Technology, E. (2002). Decision-support and Complexity in Decision Making. ... European Conference on ..., (August), 3. Retrieved from http://ou.nl/Docs/Expertise/OTEC/Publicaties/pieter-jelle beers/Pieter-Jelle Beers Paper JURE 2002.pdf

Bialowolski, P., \& Weziak-bialowolska, D. (2013). External Factors Affecting Investment Decisions of Companies, (2013), 3. Retrieved from http://www.economicsejournal.org/economics/discussionpapers/2013-44/file

Collard, S. (2009). Individual investment behaviour : A brief review of research, 3-4. Retrieved from http://www.bristol.ac.uk/medialibrary/sites/geography/migrated/documents/pfrc0901.pdf

Chandra, A. (2008). DECISION-MAKING IN THE STOCK MARKET : INCORPORATING PSYCHOLOGY WITH FINANCE Abhijeet Chandra PhD Scholar Department of Commerce \& Business Studies Jamia Millia Islamia ( A Central University ) New Delhi-110025 India, 4.

Chong, T. P., \& Lai, M. M. (2011). An empirical evidence of factors in equity selection process in Malaysia. African Journal of Business Management, 5(15), 6223. http://doi.org/10.5897/AJBM11.228 
Volume 3 Issue 6 (March 2021) PP. 01-12

DOI 10.35631/AIJBAF.36001

Chin, J. L. (2011). Women and Leadership: Transforming Visions and Current Contexts. Forum on Public Policy: A Journal of the Oxford Round Table, (2), 1-12.

Das, S., \& Jain, R. (2014). " a Study on the Influence of Demographical Variables on the Factors of Investment- a Perspective on the Guwahati Region ," 2(6), 101.

Gärling, T., Kirchler, E., Lewis, A., Raaij, F. Van, Gärling, T., Kirchler, E., ... Raaij, F. Van. (2010). Psychology , Financial Decision Making , and. Psychological Science in the Public Interest, 10(1), 7. $\quad$ Retrieved from https://www.bolton.ac.uk/Conferences/EconomicPsychology/T Garling.pdf

Haritha, P., \& Uchil, R. (2016). Conceptual framework on market factors affecting investor's sentiments and the effect of behavioral pitfalls on investment decision making. Journal of Economics and Finance, 31. Retrieved from http://www.iosrjournals.org/iosrjef/papers/SIFICO/Version-1/5. 29-34.pdf

Investment Bank. (n.d.). Retrieved from http://www.investinganswers.com/financialdictionary/investing/investment-bank-598

Islamoglu, M., Apan, M., \& Ayvali, A. (2015). Determination of Factors Affecting Individual Investor Behaviours: A Study on Bankers. International Journal of Economics and Financial Issues, 5(2), 531.

Jain, D., \& Mandot, N. (2012). Impact of Demographic Factors on Investment Decision of Investors in Rajasthan. Journal of Arts, Science \& Commerce, 2(3), 82. Retrieved from http://www.researchersworld.com/vol3/issue2/vol3_issue2_3/Paper_10.pdf

Jagongo, A., \& Mutswenje, V. S. (2014). A Survey of the Factors Influencing Investment Decisions: The Case of Individual Investors at the NSE. International Journal of Humanities and Social Science, 4(4), 18. Retrieved from http://www.ijhssnet.com/journals/Vol_4_No_4_Special_Issue_February_2014/11.pdf

Jahanzeb, A., Muneer, S., \& Rehman, S. (2012). Implication of Behavioral Finance in Investment Decision making process, 532. Retrieved from http://www.academia.edu/3473630/Implication_of_Behavioral_Finance_in_Investme nt_Decision-making_Process

Johnston, K., \& StudioD. (2016). The Effects of Macro and Microeconomics in Decision Making. Retrieved from http://smallbusiness.chron.com/effects-macromicroeconomics-decision-making-35035.html

Lee, Y., \& Management, M. (2007). The Investment Behavior, Decision Factors and Their Effects Toward Investment Performance in the Taiwan Stock Market, 3. Retrieved from http://www.jgbm.org/page/22 Yu-Je Lee .pdf

Lutfi, L. (2010). The Relationship Between Demographic Factors and Investment Decision in Surabaya, $215 . \quad$ Retrieved from https://journal.perbanas.ac.id/index.php?journal=jebav\&page=article\&op=view\&path $\% 5 \mathrm{~B} \% 5 \mathrm{D}=13$

McGraw-Hill. (n.d.). Risk and Return. Portfolio Theory.

Monisola, E. (2012). Risk and Uncertainty in Investment Decisions : an Overview, 2(4), 55. http://doi.org/10.12816/0002259

Qureshi, S. A., Rehman, K. ur, \& Hunjra, A. I. (2012). Factors Affecting Investment Decision Making of Equity Fund Managers. Wulfenia Journal, 19(10), 282.

Rajdev, A. (2013). The Effect of Demographic factors on Investment Choice of Investors: A Study on Investors of Bhopal. International Journal of Multidisciplinary Research in Social \& Management Sciences, 1(3), 111. Retrieved from http://ircjournals.org/vol1issue3/110-116.pdf 
Volume 3 Issue 6 (March 2021) PP. 01-12

DOI 10.35631/AIJBAF.36001

Ramasamy, R., \& Abar, S. K. (2015). Influence of Macroeconomic Variables on Exchange Rates. Journal of Economics, Business and Management, 3(2), 276. http://doi.org/10.7763/JOEBM.2015.V3.194

Rahman, A. A., Sidek, N. Z. M., \& Tafri, F. H. (2009). Macroeconomic determinants of Malaysian stock market. African Journal of Business Management, 3(3), 97. Retrieved from pdf/771E71F15718

http://www.academicjournals.org/journal/AJBM/article-full-text-

RIMS Executive Report. (2012). Exploring Risk Appetite and Tolerance. Continuity Central, (Apr),3.

Retrieved

from https://www.rims.org/resources/ERM/Documents/RIMS_Exploring_Risk_Appetite_R isk_Tolerance_0412.pdf

Role, T., The, P., Adler, W., \& Rose, B. (2010). Perception , Fairness , Psychological Traps , and Emotions.

Sadiq, M. N., \& Ishaq, H. M. (2014). The Effect of Demographic Factors on the Behavior of Investors during the Choice of Investment: Evidence from Twin Cities of Pakistan. Global Journal of Management and Business Research, 14(3), 47http://www.bristol.ac.uk/media-library/sites/geo. Retrieved from https://globaljournals.org/GJMBR_Volume14/7-The-Effect-of-DemographicFactors.pdf

Sajid, M. (2015). Factors Affecting Investment Decision Making : Evidence from Equity Fund Managers and Individual Investors in Pakistan, 6(9), 137. Retrieved from http://www.iiste.org/Journals/index.php/RJFA/article/viewFile/22162/23361

Singh, D. (2010). Causal Relationship Between Macro-Economic Variables and Stock Market : A Case Study for India, 30(2), 265. Retrieved from http://www.bzu.edu.pk/PJSS/Vol30No22010/Final_PJSS-30-2-07.pdf

Tseng, S., \& Search, A. I. (2012). Information Searches Affect Individual Investment Preferences: Testing a Moderating Effect of Income - ProQuest, 2(2), 134. http://doi.org/10.7763/IJSSH.2012.V2.82

Tversky, A., \& Kahneman, D. (2007). The Framing of Decisions and the Psychology of choice, 211(4481), $453 . \quad$ Retrieved from http://psych.hanover.edu/classes/cognition/papers/tversky81.pdf

Tversky, A., \& Kahneman, D. (1974). Probabilistic Reasoning. Probabilistic Reasoning. http://doi.org/10.1142/9789814291354_0006

Walia, N., \& Kiran, R. (2009). An Analysis of Investor' s Risk Perception towards Mutual Funds Services. International Journal of Business and Management, 4(5), 162. Retrieved fromhttp://citeseerx.ist.psu.edu/viewdoc/download?doi=10.1.1.687.8860\&rep=rep1\&t ype=pdf 